\title{
Estimating the age-dependent changes in carbon stocks of Scots pine (Pinus sylvestris L.) stands in Turkey
}

\author{
Jongyeol Lee $^{1} \cdot$ Doğanay Tolunay $^{2} \cdot$ Ender Makineci $^{2} \cdot$ Aydın Çömez $^{3} \cdot$ Yeong Mo Son ${ }^{4}$. \\ Raehyun Kim ${ }^{5}$ - Yowhan Son ${ }^{1,6}$
}

Received: 2 June 2015 / Accepted: 16 February 2016 / Published online: 5 April 2016

(C) INRA and Springer-Verlag France 2016

\begin{abstract}
- Key message Simulated and observed carbon stocks in Scots pine forests varied considerably with stand age. The contribution of biomass to the total forest carbon stocks increased and that of dead organic matter decreased with increasing stand age.

- Context Understanding changes in forest carbon stocks over time is important to estimate carbon inventory. Although Scots pine (Pinus sylvestris L.) is a main species in Turkey, studies on such changes are still lacking.
\end{abstract}

Handling Editor: Erwin Dreyer

Contribution of the co-authors Jongyeol Lee ran the data analysis, led discussion, and wrote the paper; Doğanay Tolunay, Ender Makineci and Aydın Çömez designed and conducted the field experiment and discussed the results; Yeong Mo Son and Raehyun Kim participated in model parameterization and discussion; and Yowhan Son wrote the paper, participated in discussion, and supervised the work.

\author{
Yowhan Son \\ yson@korea.ac.kr \\ Jongyeol Lee \\ ecomodel.lee@gmail.com \\ Doğanay Tolunay \\ dtolunay@istanbul.edu.tr \\ Ender Makineci \\ emak@istanbul.edu.tr \\ Aydın Çömez \\ aydincomez@ogm.gov.tr \\ Yeong Mo Son \\ treelove@korea.kr \\ Raehyun Kim \\ rhkim@korea.kr
}

- Aims We aimed to estimate the changes in carbon stocks, with stand age, of Scots pine stands in Turkey using field work data and a forest carbon model (FBDC model).

- Methods Biomass and dead organic matter carbon stocks were investigated to adjust the forest carbon model and to verify the model estimates. Forest carbon stocks with regards to stand age were simulated.

- Results The simulated carbon stocks were generally in clear agreement with the observed values on a stand scale. Changes in simulated and observed carbon stocks of biomass and dead

1 Department of Environmental Science and Ecological Engineering, Graduate School, Korea University, Seoul, Korea

2 Department of Soil Science and Ecology, Faculty of Forestry, Istanbul University, Istanbul, Turkey

3 Research Institute for Forest Soil and Ecology, Eskişehir, Turkey

4 Division of Forest Industry Research, National Institute of Forest Science, Seoul, Korea

5 Division of Research Planning and Coordination, National Institute of Forest Science, Seoul, Korea

6 Department of Biological and Environmental Sciences, Qatar University, Doha, Qatar 
organic matter varied with stand age. The contribution of biomass to total forest carbon stocks increased, and that of dead organic matter decreased, with increasing stand age.

- Conclusion We found that the carbon stocks in each pool and their contribution to the total forest carbon stocks varied with stand age. Our results are expected to contribute to the understanding of annual changes in the carbon stocks of Turkish forests.

Keywords Forest carbon - Scots pine - FBDC model · Biomass $\cdot$ Dead organic matter $\cdot$ Verification

\section{Introduction}

Forest ecosystems contain a substantial amount of carbon (C) and make a significant contribution to the global $\mathrm{C}$ sink (Dixon et al. 1994; Pan et al. 2011). Maintaining forest $\mathrm{C}$ sinks has also become important to mitigate global climate change. In order to implement successful forest management policies, a scientific basis is required (Tewari 2015). Thus, forest $\mathrm{C}$ dynamics have been quantified at various spatial and temporal scales (Dixon et al. 1994; Luyssaert et al. 2010; Pan et al. 2011).

Forest $\mathrm{C}$ stocks and their changes have been estimated directly through field measurements. However, there are a number of limitations with this method, including uncertainties in data extrapolation at temporal and spatial scales, and high demands on labor and cost (Fang et al. 2014). Ecosystem modeling is a method frequently applied to estimate forest $\mathrm{C}$ stocks and their changes on regional and global scales (Kurz and Apps 1999; Luyssaert et al. 2010; Sitch et al. 2008). In addition, ecosystem models can estimate $\mathrm{C}$ cycles at different time and space more efficiently than direct measurement (Liski et al. 2002; Pilli et al. 2013). Considering these advantages, such models represent an effective alternative to field measurements.

Scots pine (Pinus sylvestris L.) is a main species in European forests and occupies 1.48 million ha of the total of 21.68 million ha of Turkish forests. Accordingly, understanding $\mathrm{C}$ dynamics in Scots pine forests is an important step toward estimation of the total $\mathrm{C}$ stock in Turkish forests. Previous studies have focused mainly on estimating $\mathrm{C}$ stocks in biomass using forest inventory data, allometry functions, and constant biomass expansion factors (Misir 2013; Sivrikaya et al. 2013; Tolunay 2011; Yolasiğmaz and Keles 2009). C stocks in dead organic matter (e.g., O horizon, dead wood, and mineral soil) have been poorly studied (Tolunay and Çömez 2008). The lack of measurement makes it hard to understand the $\mathrm{C}$ dynamics in Scots pine forests in Turkey.

Ecosystem models allow us to simulate the forest $\mathrm{C}$ cycle, including biomass and dead organic matter (Kim et al. 2015a). However, insufficient data on Turkish forests makes it hard to run most forest $\mathrm{C}$ models. The forest biomass and dead organic matter C (FBDC) model (previously known as the KFSC model) requires only few parameters and input data (Lee et al.
2014; Yi et al. 2013). For this reason, it seemed highly suitable to simulate $\mathrm{C}$ dynamics in the Scots pine forests of Turkey. The FBDC model has successfully estimated the forest $\mathrm{C}$ dynamics on a national scale over several decades in Korea (Lee et al. 2014, 2015; Park et al. 2013a; Yi et al. 2013).

In this study, we aimed to elucidate the annual changes in (1) the $\mathrm{C}$ stocks of above- and belowground biomass, the $\mathrm{O}$ horizon, dead wood, and mineral soil; and (2) the distribution of $\mathrm{C}$ stocks among $\mathrm{C}$ pools in Scots pine stands. Field work was conducted to estimate the model input and parameters of the FBDC model and to measure the $\mathrm{C}$ stocks in each pool. The FBDC model was adjusted to fit the study site using empirical data and previous studies. The model estimates of biomass, O horizon, aboveground dead wood, and mineral soil were then verified by comparing them with the corresponding observed $\mathrm{C}$ stocks. The change in contribution of each pool to total forest $\mathrm{C}$ stocks with increasing stand age was also estimated.

\section{Materials and methods}

\subsection{Site description and field work}

In this study, the data of stand characteristics and $\mathrm{C}$ stocks of above- and below-ground biomass, O horizon, aboveground dead wood, and mineral soil reported in Çömez (2010) were used (Table 1). This study was conducted in Scots pine forests in the Sundiken Mountains, which are located in the central Anatolia region of Turkey $\left(39^{\circ} 56^{\prime}-39^{\circ} 59^{\prime} \mathrm{N}, 31^{\circ} 03^{\prime}-31^{\circ} 11^{\prime} \mathrm{E}\right)$. According to the WorldClim 1.4 data set, the annual mean temperatures range between $7.2^{\circ} \mathrm{C}$ and $9.2^{\circ} \mathrm{C}$ and the annual mean precipitation was about 700-900 mm (Çömez 2010). The soil group and texture was almost Luvisol and sandy clay loam, and acidity $(\mathrm{pH})$ ranged from 5.0 to 6.6 in the research area (Çömez 2010; IUSS Working Group WRB 2006).

A total of 63 sample plots was selected from Scots pine stands with different ages (8- to 177-year-old), diameters at breast height (DBH; 0-46.79 cm), tree heights (0.9-29.38 m), and canopy covers (10-90\%) in 2008. The areas of the sample plots varied between $100 \mathrm{~m}^{2}$ and $400 \mathrm{~m}^{2}$. The mean age of each plot was determined by counting the annual rings in samples taken with an increment borer from five trees. One tree with a mean DBH of each sample plot was excavated in order to weigh individual tree components (stem, foliage, and branch). The tree roots, the other tree component, were sampled and weighed in 24 sample plots due to limitations of labor and cost. Based on the data, a regression model of each tree component was developed according to the $\mathrm{DBH}$ and tree height. The mass 
Table 1 Stand characteristics and carbon (C) stocks in the study site. $D B H$ Diameter at breast height

\begin{tabular}{llll}
\hline & Minimum & Mean & Maximum \\
\hline Stand characteristics & & & \\
DBH (cm) & 0 & 29.24 & 46.79 \\
Height (m) & 0.85 & 16.22 & 29.38 \\
Mean age (year) & 8 & 85.46 & 177 \\
Canopy cover (\%) & 10 & 56.45 & 90 \\
Stand density (trees ha $\left.{ }^{-1}\right)$ & 50 & 2658.51 & 40,000 \\
C stocks (Mg C ha $\left.{ }^{-1}\right)$ & & & \\
Stem & 0.91 & 71.34 & 202.65 \\
Branch & 0.44 & 12.56 & 37.54 \\
Foliage & 0.66 & 4.05 & 8.62 \\
$\quad$ Aboveground biomass & 2.21 & 87.95 & 247.93 \\
Root & 0.48 & 17.47 & 46.92 \\
$\quad$ Total biomass & 2.69 & 105.42 & 294.85 \\
O horizon & 2.15 & 15.37 & 34.91 \\
Aboveground dead wood & 0 & 0.94 & 4.62 \\
Mineral soil (1 m depth) & 53.79 & 99.65 & 160.84 \\
\hline
\end{tabular}

of tree components in each plot was estimated using these regression models. The $\mathrm{C}$ stocks in 44 sample plots were selected to estimate growth models, and those in 19 plots were used to verify the models.

$\mathrm{O}$ horizon samples were taken randomly from an area of $0.25 \mathrm{~m}^{2}$, with four replications in each sample plot. All dead wood materials in sample plots were collected and weighed. To estimate the $\mathrm{C}$ stocks in the mineral soil, one soil pit was dug at a random point in each sample plot. Soil samples were collected from the different mineral soil horizons up to $1 \mathrm{~m}$ in depth with 1-L soil corers. The soil samples were air-dried and sieved with a 2-mm screen. To estimate the soil bulk density, all roots and coarse material bigger than $2 \mathrm{~mm}$ were separated from the mineral soil.

Subsamples of tree components, $\mathrm{O}$ horizon, and aboveground dead wood were dried at $65{ }^{\circ} \mathrm{C}$ and soil samples were dried at $105{ }^{\circ} \mathrm{C}$ to constant weight. Then, $\mathrm{C}$ concentration was measured using a $\mathrm{CHN}$ analyzer (LECO TruSpec 2000 Analyzer; LECO Corporation, St. Joseph, MI). To measure the amount of $\mathrm{C}$ in trees, $\mathrm{O}$ horizon, aboveground dead wood, and mineral soil, the $\mathrm{C}$ concentration was multiplied by the dry weight. In particular, the $\mathrm{C}$ stock at each soil depth was measured from the $\mathrm{C}$ concentration, bulk density and layer thickness, and the total $\mathrm{C}$ stocks in the mineral soil were determined by summing the $\mathrm{C}$ contents at all soil depths. Consequently, the $\mathrm{C}$ stocks $\left(\mathrm{Mg} \mathrm{C} \mathrm{ha}{ }^{-1}\right)$ in the total biomass, $\mathrm{O}$ horizon, mineral soil, and aboveground dead wood were $2.69-294.85,2.15-34.91,53.79-$ 160.84 , and $0-4.62$, respectively.

\subsection{FBDC model structure and parameterization}

The FBDC model is a generic model, simulating the complex $\mathrm{C}$ dynamics of dead organic matter with simple biomass regression models and only a few parameters (Lee et al. 2014; Yi et al. 2013). The main feature of this model is the low level of required input data and its high applicability at various spatial and temporal scales. It was first called the Korean Forest Soil Carbon (KFSC) model (Lee et al. 2014; Yi et al. 2013). We changed the name to the FBDC model because it can simulate $\mathrm{C}$ dynamics for both biomass and dead organic matter. This model consists of a biomass compartment and a dead organic matter compartment (Yi et al. 2013). The biomass category includes five tree components: the stem, branch, foliage, coarse root, and fine root pools, and their growth rates were estimated using a yield table and allometric function. The dead organic matter compartment includes the five primary dead organic matter pools (aboveground woody debris from stems, aboveground woody debris from branches, aboveground litter, belowground woody debris, and belowground litter) and the three secondary dead organic matter pools (aboveground humus, belowground humus, and soil organic C) that were classified by their source and degree of decomposition and kinetics (Lee et al. 2014). The following $\mathrm{C}$ processes were simulated in this model: (1) C stocks in biomass increase by sequestering atmospheric C; (2) a proportion of stems, branches, foliage, and coarse roots input organic $\mathrm{C}$ into primary dead organic matter pools (the $\mathrm{O}$ horizon and dead wood); (3) the annual production of dead fine roots becomes input to the mineral soil pool; (4) $\mathrm{C}$ in the $\mathrm{O}$ horizon and dead wood decay to the mineral soil $\mathrm{C}$ pool; and (5) $\mathrm{C}$ in the mineral soil finally decays to atmospheric C. Because the FBDC model was not parameterized for Scots pine forests, an adjustment was required. To estimate the growth function of each tree compartment with stand age, field data were used. The Gompertz function was used to formulate non-linear growth of tree with stand age $\{$ Biomass $=\mathrm{a} * \exp [\mathrm{b} * \exp (\mathrm{c} *$ Stand age)]; a, b, and c are constants $\}$. The best-fitting model for each compartment was estimated with the PROC NLIN procedure in SAS 9.4 due to the non-linearities (Table 2). Measurement data of biomass $\mathrm{C}$ from 44 plots were used in this procedure. The actual growth of the trees in each plot, unfortunately, did not exactly follow the best-fitting functions due to heterogeneity in productivity among the plots. In order to calibrate for this heterogeneity, the following factor was invented (Lee et al. 2014):

Growth Modifier $=\frac{\text { Stem } C_{o b s}}{\text { Stem } C_{\text {est }}}$

where Stem $\mathrm{C}_{\mathrm{obs}}$ is the observed stem C stock from field work, 
Table 2 Regression model of each biomass compartment. The regression models were based on the Gompertz function. Biomass carbon (C) stock $\left(\mathrm{Mg} \mathrm{C} \mathrm{ha}{ }^{-1}\right)$ for each compartment (age) $=\mathrm{a} \times \exp$ $[\mathrm{b} \times \exp (\mathrm{c} \times$ age $)]$. The annual increase of $\mathrm{C}$ stock was calculated by the first-order derivative of each function

\begin{tabular}{lrrr}
\hline Compartment & \multicolumn{2}{c}{ Parameter } & \\
\cline { 2 - 4 } & $\mathrm{a}$ & $\mathrm{b}$ & $\mathrm{c}$ \\
\hline Stem & 163.0 & -3.13 & -0.016 \\
Branch & 50.0 & -3.38 & -0.010 \\
Foliage & 4.5 & -2.47 & -0.100 \\
Coarse root & 49.2 & -2.83 & -0.012 \\
\hline
\end{tabular}

and Stem $\mathrm{C}_{\text {est }}$ is the estimated stem C stock from the bestfitting function at a certain stand age. The growth modifiers, as input data for the FBDC model, were multiplied by the bestfitting regression model of each biomass compartment in each plot. These modifiers determined the level of biomass growth and annual dead organic matter input to forest soils. Because fine roots were not investigated in this study, the following ratio of fine root to foliage with stand age was used to estimate the C stocks in fine roots (Vanninen et al. 1996):

Fine root $:$ Foliage $=$ Stand age $+0.1012\left(r^{2}=0.67\right)$

By multiplying these ratios with the $\mathrm{C}$ stocks in the foliage, the $\mathrm{C}$ stocks in the fine roots could be estimated.

The substitution of parameters was needed in the FBDC model in order to simulate the $\mathrm{C}$ cycle in the Scots pine plots (Table 3). Most parameters were substituted by parameters that represented the regional environment. A detailed description of the dead organic matter $\mathrm{C}$ processes in the FBDC model is given by Yi et al. (2013).

\subsection{Initialization and simulation of C stocks}

Due to the lack of data on $\mathrm{C}$ stocks in dead organic matter pools at plots with an age of 0 , these pools needed to be initialized. The dead organic matter $\mathrm{C}$ pools in the study sites were initialized with a spin-up process (Kurz et al. 2009; Lee et al. 2014). Due to the maximum stand age (177 years old) and the management plans of Turkish General Directorate of Forestry, the spin-up process was conducted by 200 -year interval clear cutting. That process was conducted until the quasi-steady state in which the difference in the $\mathrm{C}$ stocks in the mineral soil pool between two successive rotations was less than $1 \%$.

After the initialization process, the forest $\mathrm{C}$ dynamics in each plot was simulated over the stand age in 2008 . The simulated average and standard deviation of the $\mathrm{C}$ stocks in the biomass, O horizon, aboveground dead wood, and mineral soil were estimated. Because the $\mathrm{C}$ dynamics in each plot from 1 to 200 years old could be simulated with the FBDC model, the continuous change in the simulated $\mathrm{C}$ stock over the stand age in each pool (up to 200 years old) was also provided. The changes in the simulated $\mathrm{C}$ stocks in the $\mathrm{C}$ pools were the averaged value among the sampling plots from 1 to 200 years of age.

\subsection{Verification}

The simulated C stocks in the tree biomass (stems, branches, foliage, and roots), O horizon, aboveground dead wood, and mineral soil at the stand age in 2008 were thoroughly verified by comparing them to the corresponding observed $\mathrm{C}$ stocks at the plot scale. For this verification procedure, we used the measurement data from 19 plots that were not used to estimate
Table 3 Parameters of the forest biomass and dead organic matter carbon (FBDC) model. AWDS Aboveground woody debris from the stem, $A W D B$ aboveground woody debris from branches, $A L T$ aboveground litter, $B W D$ belowground woody debris, $B L T$ belowground litter, $A H U M$ aboveground humus, BHUM belowground humus, $S O C$ soil organic carbon

\begin{tabular}{lll}
\hline Parameter & Value & Reference \\
\hline $\begin{array}{l}\text { Turnover rate }\left(\text { year }^{-1}\right) \\
\text { Stem }\end{array}$ & 0.0043 & Liski et al. (2002) \\
Branch & 0.027 & Liski et al. (2002) \\
Foliage & 0.25 & Muukkonen (2005); Çömez (unpublished) \\
Coarse root & 0.027 & Liski et al. (2002) \\
Fine root & 0.84 & Landsberg et al. (2005) \\
Decay constant (k; year $\left.{ }^{-1}\right)$ & & \\
AWDS and AWDB & 0.028 & Liski et al. (2002) \\
ALT & 0.341 & Sariyildiz (2008) \\
BWD & 0.028 & Assumed to equal the decay constant of AWDS \\
BLT & 0.462 & Kim (2002) \\
AHUM and BHUM & 0.012 & Liski et al. (2005) \\
SOC & 0.0012 & Liski et al. (2005) \\
\hline
\end{tabular}


the best-fitting models. The $\mathrm{C}$ stocks in the dead organic matter pools were verified with the measurement data from 63 plots. The accuracy of the model estimates was estimated as the slope and $r^{2}$ of the linear relationship between the simulated and observed C stocks with SAS 9.4 software. The simulated C stocks in each biomass pool (the stems, branches, foliage, and roots) were verified. The observed $\mathrm{C}$ stocks in the $\mathrm{O}$ horizon were compared to the sum of the simulated $\mathrm{C}$ stocks in the aboveground woody debris from branches and the aboveground fallen leaves. The $\mathrm{C}$ stocks in the aboveground woody debris from stems in the FBDC model corresponded to those of the aboveground dead wood. Finally, the observed $\mathrm{C}$ stocks in the mineral soil were compared to the sum of the simulated $\mathrm{C}$ stocks in dead fine roots, humus, and the other mineral soil.

\section{Results}

\subsection{Verification of model estimates}

The simulated $\mathrm{C}$ stocks in the biomass, $\mathrm{O}$ horizon, and mineral soil were in clear agreement with the corresponding observed $\mathrm{C}$ stocks at the stand scale (Table 4 ). The simulated C stocks in the stems, branches, foliage, and roots were accurate. The difference between the simulated and observed $\mathrm{C}$ stocks of each tree component was, on average, less than $10 \%$ $\left(r^{2} \geq 0.93\right)$ and the slope of each pool was not significantly biased $(\mathrm{a}=1 ; P>0.05)$. The root mean square errors (RMSEs) of the simulated $\mathrm{C}$ stock of tree components were also less than $4 \mathrm{Mg} \mathrm{C} \mathrm{ha}^{-1}$. Compared to biomass $\mathrm{C}$ pools, the dead organic matter $\mathrm{C}$ pools showed a high level of uncertainty. The simulated $\mathrm{C}$ stocks in the $\mathrm{O}$ horizon and mineral soil

Table 4 Linear relationship between simulated and observed carbon stocks. Simulated value $=a \times$ Observed value $(a=$ coefficient of slope $)$. All $P$ values of slopes in the regression models were significant $(\mathrm{a} \neq 0)$. $R M S E$ Root mean square error

Pool All sample plots

Slope $\quad r^{2} \quad$ RMSE

$\left(\mathrm{Mg} \mathrm{Cha}^{-1}\right)$

\begin{tabular}{llll}
\hline Biomass & & & \\
Stem & 1.00 & 1.00 & 0 \\
Branch & 0.90 & 0.93 & 2.94 \\
Foliage & 1.03 & 0.94 & 1.08 \\
$\quad$ Roots & 0.94 & 0.95 & 3.52 \\
Dead organic matter & & & \\
$\quad$ O horizon & 1.07 & 0.52 & 11.84 \\
$\quad$ Mineral soil & 1.02 & 0.77 & 68.74 \\
$\quad$ Aboveground dead wood & $4.26^{*}$ & 0.25 & 10.54
\end{tabular}

$* P<0.05$ [slope of linear relationship is significantly different from 1 $(a \neq 1)]$ were $7 \%$ and $2 \%$ more than the observed values and these estimates were not significantly biased $(\mathrm{a}=1 ; P>0.05)$. However, they showed lower prevision $\left(r^{2}=0.52,0.77\right)$ and high levels of root mean square errors (11.84 and 68.74 Mg C $\mathrm{ha}^{-1}$ ). Especially, the simulated $\mathrm{C}$ stocks in the aboveground dead wood were overestimated by about 4.3 times, with low precision $\left(r^{2}=0.25\right)$ and high $\operatorname{RMSE}\left(10.54 \mathrm{Mg} \mathrm{C}^{-1}\right)$. In addition, the slope of linear relationship for aboveground dead wood was also significantly biased $(a \neq 1 ; P<0.05)$.

\subsection{Changes in forest $\mathrm{C}$ stocks with stand age}

The simulated biomass $\mathrm{C}$ stocks gradually increased from $0.61 \mathrm{Mg} \mathrm{C} \mathrm{ha}^{-1}$ to $235.25 \mathrm{Mg} \mathrm{C}^{-1}$, and the observed biomass $\mathrm{C}$ stocks also demonstrated an increase with increasing stand age (Fig. 1a). In contrast, the simulated $\mathrm{C}$ stocks in the $\mathrm{O}$ horizon had an inconsistent relationship with stand age (Fig. 1b). The simulated $\mathrm{C}$ stocks in the $\mathrm{O}$ horizon decreased to $17.35 \mathrm{MgC} \mathrm{ha}^{-1}$ on average at the early development stage, and then gradually increased to $29.65 \mathrm{Mg} \mathrm{C}^{-1}$. The simulated $\mathrm{C}$ stocks in the aboveground dead wood also exhibited an inconsistent relationship with stand age (Fig. 1c). The simulated $\mathrm{C}$ stocks in aboveground dead wood decreased from 20.33 $\mathrm{MgC} \mathrm{ha}^{-1}$ to $7.07 \mathrm{Mg} \mathrm{C} \mathrm{ha}^{-1}$, and then increased to $20.25 \mathrm{Mg} \mathrm{C}^{-1}$. The observed $\mathrm{C}$ stocks in the $\mathrm{O}$ horizon and aboveground dead wood differed from the simulated $\mathrm{C}$ stocks. Compared to the other dead organic matter $\mathrm{C}$ pools, the simulated mineral soil $\mathrm{C}$ stocks were insensitive to stand age (Fig. 1d). The simulated $\mathrm{C}$ stocks in the mineral soil ranged from $108.60 \mathrm{Mg} \mathrm{C} \mathrm{ha}^{-1}$ to $123.36 \mathrm{Mg} \mathrm{C}^{-1}$ during the early development stage.

The contribution of each $\mathrm{C}$ pool to the total $\mathrm{C}$ stock also varied with stand age. In general, the contribution of biomass increased while those of the dead organic matter pools decreased with increasing stand age (Fig. 2). The simulated results showed that the biomass pool explained between $0.22 \%$ and $53.00 \%$ of the total $\mathrm{C}$ stocks relative to stand age. The contributions of the $\mathrm{O}$ horizon, dead wood (including aboveground dead wood and dead coarse roots) and mineral soil decreased with increasing stand age while those of the $\mathrm{O}$ horizon and dead wood became constant. The contributions of the simulated $\mathrm{C}$ stocks in the $\mathrm{O}$ horizon, dead wood, and mineral soil pools decreased from a maximum of $32.57 \%$, $24.06 \%$, and $53.42 \%$ to $6.97 \%, 12.23 \%$, and $27.80 \%$, respectively.

\section{Discussion}

\subsection{Reliability of the model estimates}

Forest $\mathrm{C}$ models can be used to estimate forest $\mathrm{C}$ stocks but such models often require a number of input data and 

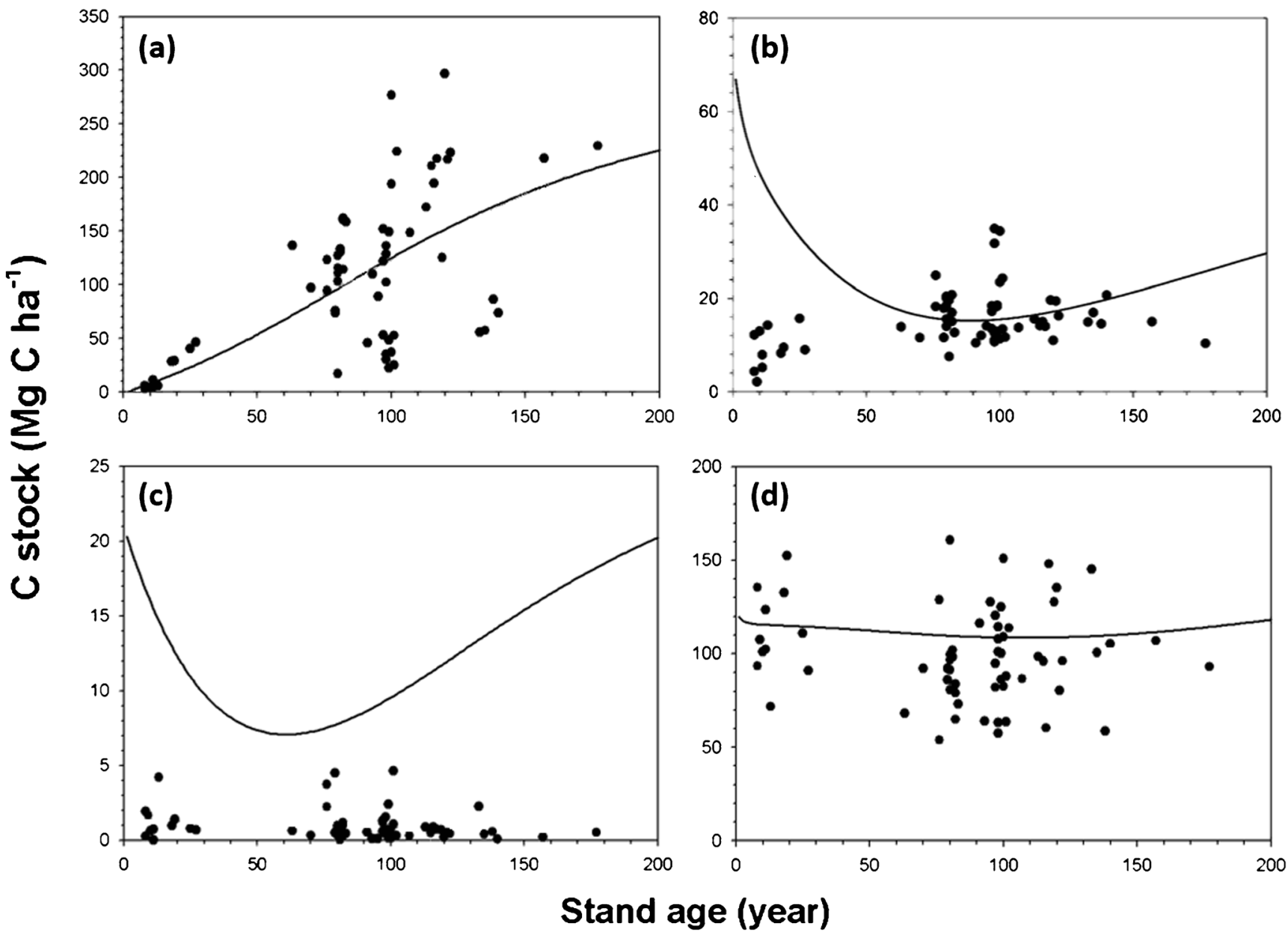

Fig. 1 Relationship between simulated (model simulation; black solid line) and observed (black dots) carbon (C)) stocks with stand age in a biomass, b O horizon, $\mathbf{c}$ aboveground dead wood, and $\mathbf{d}$ mineral soil

parameters. For example, many forest $\mathrm{C}$ models (e.g., Yasso, Forest-DNDC, and RothC) require data on soil

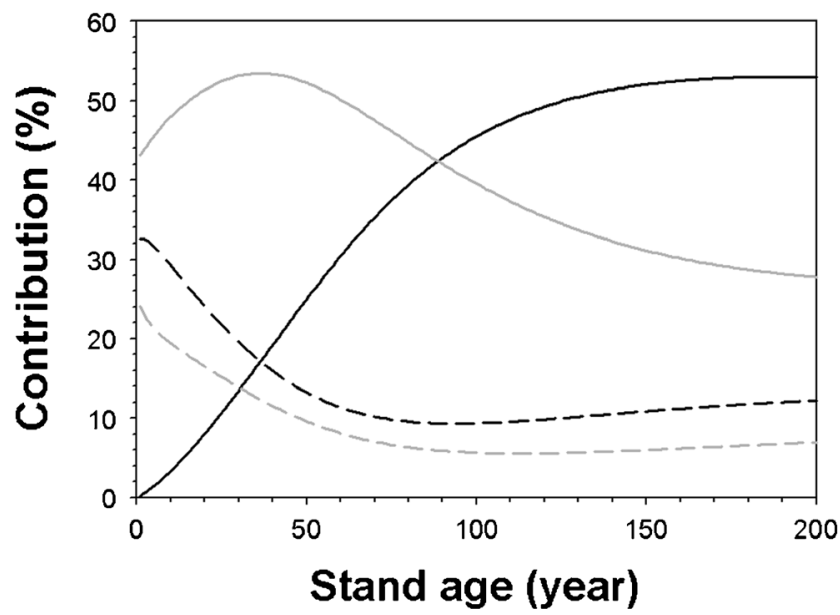

Fig. 2 Contributions of simulated carbon (C) stock in each pool to total forest $\mathrm{C}$ stock with increasing stand age. Black solid and dashed lines Contribution of biomass and dead wood (aboveground dead wood and dead coarse roots), respectively; grey solid and dashed lines contribution of the mineral soil and $\mathrm{O}$ horizon, respectively properties and various climatic and vegetation conditions (Chertov et al. 2001; Coleman and Jenkinson 2008; Lee et al. 2010; Liski et al. 2005). However, our verification results showed that the model estimates agreed well with observations, especially for $\mathrm{C}$ stocks in the biomass (Table 4). An accurate estimation of $\mathrm{C}$ stocks in each tree compartment is crucial to estimate $\mathrm{C}$ stocks in the biomass and annual input to dead organic matter pools. In this study, the accurate estimation of $\mathrm{C}$ stocks in each tree compartment was attributed to the wide range of stand age in sample plots and the small variation in spatial scale. Allometric relationships between tree compartments vary with stand age (Jalkanen et al. 2005; Lehtonen et al. 2004) and climatic factors (Friedlingstein et al. 1999; Litton et al. 2007). The range of stand age in sample plots was wide enough to represent the growth pattern of each tree component during its life cycle. In addition, variation in allometric relationships by climatic factors might be constrained due to proximity of the geographical location of sample plots. 
The simulated $\mathrm{C}$ stocks in the $\mathrm{O}$ horizon and mineral soil pools also seemed accurate because the simulated $\mathrm{C}$ stocks were not significantly biased. In addition, the simulated and observed $\mathrm{C}$ stocks in these pools were also similar on average. However, the relatively lower $r^{2}$ and high level of RMSE of the simulated C stocks in the $\mathrm{O}$ horizon and mineral soil indicated uncertainties. This phenomenon seemed to be attributed mainly to the parameter set (Peltoniemi et al. 2006). Most parameters used in this study were cited from studies conducted in other regions. These parameters thus did not perfectly represent the environment of the study site in this study. To improve model performance, using a local parameter set will be needed.

$\mathrm{C}$ stocks in the $\mathrm{O}$ horizon during the early development period and in aboveground dead wood, especially, were overestimated (Fig. 1; Table 4). During simulation, we assumed that only the stem was harvested and the other tree compartments were left. Branch became input to the $\mathrm{O}$ horizon pool due to limitations of model structure and assumption. This assumption could lead to overestimation of the simulated $\mathrm{C}$ stocks in $\mathrm{O}$ horizon during early period. The overestimation of aboveground dead wood was attributed mainly to Turkish forest management policies in Turkey, which attempt to suppress pest-borne disease or epidemics, as well as the use of harvest residue and dead wood for fire fuel by local villagers. Accordingly, consideration of forest management policies and practices can improve model accuracy (Kim et al. 2015c; Verkerk et al. 2011; Wang et al. 2013).

\subsection{Comparison of the changes in simulated and observed C stocks with stand age}

The changes in the simulated $\mathrm{C}$ stocks with increasing stand age were analyzed by model simulation. The relationship between simulated and observed $\mathrm{C}$ dynamics with stand age in dead organic matter differed greatly (Fig. 1). The differences between the simulated and observed $\mathrm{C}$ stocks in the $\mathrm{O}$ horizon and aboveground dead wood were especially substantial in the initial stages of stand development. These differences might be attributed to the initial C stocks in those pools (Peltoniemi et al. 2006). Initial C stocks in dead organic matter are affected by the history of land use and management (Jandl et al. 2007). For example, the initial $\mathrm{C}$ stocks in dead organic matter could decrease if the harvest interval was shortened (Park et al. 2013b). In this study, a 200-year harvest and no land-use change were assumed. Unfortunately, there were no available data with respect to management and land-use history for our study site. In addition, the $\mathrm{C}$ stocks in dead organic matter were measured at the same time in 63 plots that exhibited wide spatial heterogeneity (Fig. 1). This made it difficult to establish a clear pattern of changes in the observed forest $\mathrm{C}$ stocks
(Mohren et al. 2012; Rantakari et al. 2012; Yuan et al. 2013). Long-term monitoring and land-use data are required to enable a more accurate estimate of forest $\mathrm{C}$ dynamics with stand age.

Most previous studies have focused on the $\mathrm{C}$ stocks in Scots pine stands at certain stand ages (Helmissari et al. 2002; Lehtonen et al. 2004; Muukkonen 2007; Petersson and Ståhl 2006). Our integrative analysis, designed to understand changes in the contributions of $\mathrm{C}$ pools to the total forest $\mathrm{C}$ stocks with stand age, was thus worthwhile (Fig. 2). These changes in contributions could also be used as conversion factors for estimating $\mathrm{C}$ stocks in other pools based on the measurement of one pool. The contribution of biomass increased and that of dead organic matter decreased with increasing stand age. The rise in biomass $\mathrm{C}$ stocks overwhelmed that of dead organic matter as the stands matured. However, this relationship may be less accurate for Scots pine forests in other climatic zones. A different biomass growth rate or decay rate of dead organic matter could affect the ratio of each $\mathrm{C}$ pool to the total forest $\mathrm{C}$ stock (Khaine and Woo 2015; Vucetich et al. 2000; Zhu et al. 2010). Any difference in forest management could also affect those ratios (Kim et al. 2015b; Park et al. 2013b). Thus, the ratios should be adjusted to a regional scale in order to improve applicability and accuracy.

Forest $\mathrm{C}$ stocks generally increased with increasing stand age and decreasing frequency of harvest rotation (Jiang et al. 2002; Liski et al. 2001). In this study, the contribution of the biomass pool to the total C stocks becomes particularly dominant as stand age increases (Fig. 2). Harvests instantly reduce biomass $\mathrm{C}$ stocks and annual input of dead organic matters decrease with decreasing biomass $\mathrm{C}$ stocks. More frequent harvests suppress a level of biomass $\mathrm{C}$ stocks and increase in dead organic matter $\mathrm{C}$ stocks. Thus, forest $\mathrm{C}$ storage and sequestration could decrease under a harvest rotation that is shorter than 200 years.

\section{Conclusions}

We elucidated annual changes in $\mathrm{C}$ stocks of each pool using empirical data and model simulation. The $\mathrm{C}$ stocks in $\mathrm{C}$ pools and their contribution to total forest $\mathrm{C}$ stocks varied greatly with stand age. A forest $\mathrm{C}$ modeling method, simulating annual forest $\mathrm{C}$ dynamics with a small data set, was also developed. Our results will contribute to the understanding of the time series of $\mathrm{C}$ dynamics in Turkish forests.

\section{Compliance with ethical standards}

Funding This work was supported by the Turkish Research Institute for Forest Soil and Ecology under Grant ESK-06 (6303)/2007-2010; the Korea Forest Service under Grant S111314L100120; the Korea Ministry of Environment under Grant C314-00131-0408-0; and the Korea University Grant (2015). 


\section{References}

Chertov OG, Komarov AS, Nadporozhskaya M, Bykhovets SS, Zudin SL (2001) ROMUL - a model of forest soil organic matter dynamics as a substantial tool for forest ecosystem modeling. Ecol Model 138:289-308

Coleman K, Jenkinson D (2008) A model for the turnover of carbon in soil, model description and windows user guide. Rothamstead Research, Hertfordshire

Çömez A (2010) Sündiken Dağlar'ında sarıçam (Pinus sylvestris L.) meșcerelerinde karbon birikiminin belirlenmesi (in Turkish with English summary). Doctoral dissertation, Istanbul University.

Dixon RK, Solomon AM, Brown S, Houghton RA, Trexler MC, Wisniewski J (1994) Carbon pools and flux of global forest ecosystems. Science 263:185-190

Fang J, Guo Z, Hu H, Kato T, Muraoka H, Son Y (2014) Forest biomass carbon sinks in East Asia, with special reference to the relative contributions of forest expansion and forest growth. Glob Chang Biol 20:2019-2030

Friedlingstein P, Jeol G, Field CB, Fung IY (1999) Toward an allocation scheme for global terrestrial carbon models. Glob Chang Biol 5: $755-770$

Helmissari H-S, Makkonen K, Kellomäki S, Valtonen E, Mälkönen E (2002) Below- and above-ground biomass, production and nitrogen use in Scots pine stands in eastern Finland. For Ecol Manag 165: $317-326$

IUSS Working Group WRB (2006) World reference base for soil resources 2006. Food and Agriculture Organization of the United Nations, Rome

Jalkanen A, Mäkipää R, Ståhl G, Lehtonen A, Petersson H (2005) Estimation of the biomass stock of trees in Sweden: comparison of biomass equations and age-dependent biomass expansion factors. Ann For Sci 62:845-851

Jandl R, Linder M, Vesterdal L, Bauwens B, Baritz R, Hagedorn F, Johnson DW, Minkkinen K, Byrne K (2007) How strongly can forest management influence soil carbon sequestration? Geoderma 137:253-268

Jiang H, Apps MJ, Peng C, Zhang Y, Liu J (2002) Modelling the influence of harvesting on Chinese boreal forest carbon dynamics. For Ecol Manag 169:65-82

Khaine I, Woo SY (2015) An overview of interrelationship between climate change and forests. For Sci Technol 11:11-18

Kim C (2002) Mass loss rates and nutrient dynamics of decomposing fine roots in a sawtooth oak and Korean pine stands. J Ecol Environ 125:235-239

Kim H, Kim Y-H, Kim R, Park H (2015a) Reviews of forest carbon dynamics models that use empirical yield curves: CBM-CFS3, CO2FIX, CASMOFOR, EFISCEN. For Sci Technol 11:212-222

Kim M, Lee W-K, Kim Y-S, Lim C-H, Song C, Park T, Son Y, Son YM (2015b) Impact of thinning intensity on the diameter and height growth of Larix kaempferi stands in central Korea. For Sci Technol:1-11. doi: 10.1080/21580103.2015.1075435

Kim S, Yoon TK, Han S, Han SH, Lee J, Kim C, Lee S-T, Seo KW, Yang A-R, Son Y (2015c) Initial effects of thinning on soil carbon storage and base cations in a naturally regenerated Quercus spp. forest in Hongcheon, Korea. For Sci Technol 11:172-176

Kurz WA, Apps MJ (1999) A 70-year retrospective analysis of carbon fluxes in the Canadian forest sector. Ecol Appl 9:526-547

Kurz WA, Dymond CC, White TM, Stinson G, Shaw CH, Rampley GJ, Smyth C, Simpson BN, Neilson ET, Trofymow JA, Metsaranta J, Apps MJ (2009) CBM-CFS3: a model of carbon-dynamics in forestry and land-use change implementing IPCC standards. Ecol Model 220:480-504

Landsberg J, Mäkelä A, Sievänen R, Kukkola M (2005) Analysis of biomass accumulation and stem size distributions over long periods in managed stands of Pinus sylvestris in Finland using the 3-PG model. Tree Physiol 25:781-792

Lee AR, Yi K, Son Y, Kim RH, Kim CS, Park GS, Lee KH, Yi MJ (2010) Approaches for developing a Korean model through analysis of overseas forest soil carbon models (in Korean with English summary). J Korean For Soc 99:791-801

Lee J, Yoon TK, Han S, Kim S, Yi MJ, Park GS, Kim C, Son YM, Kim R, Son Y (2014) Estimating the carbon dynamics of South Korean forests from 1954 to 2012. Biogeosciences 11:4637-4650

Lee J, Han SH, Kim S, Chang H, Yi MJ, Park GS, Kim C, Son YM, Kim $\mathrm{R}$, Son Y (2015) Estimating the changes in forest carbon dynamics of Pinus densiflora and Quercus variabilis forests in South Korea under the RCP 8.5 climate change scenario (in Korean with English summary). Korean J Agric Meteorol 17:35-44

Lehtonen A, Mäkipää R, Heikkinen J, Sievänen R, Liski J (2004) Biomass expansion factors (BEFs) for Scots pine, Norway spruce and birch according to stand age for boreal forests. For Ecol Manag 188:211-224

Liski J, Pussinen A, Pingoud K, Makipaa R, Karjalainen T (2001) Which rotation length is favourable to carbon sequestration? Can J For Res 31:2004-2013

Liski J, Perruchoud D, Karjalainen T (2002) Increasing carbon stocks in the forest soils of western Europe. For Ecol Manag 169:159-175

Liski J, Palosuo T, Peltoniemi M, Sievänen R (2005) Carbon and decomposition model Yasso for forest soils. Ecol Model 189:168-182

Litton CM, Raich JW, Ryan MG (2007) Carbon allocation in forest ecosystems. Glob Chang Biol 13:2089-2109

Luyssaert S, Ciais P, Piao SL, Schulze E-D, Jung M, Zaehle S, Schelhaas MJ, Reichstein M, Churkina G, Papale D, Abril G, Beer C, Grace J, Loustau D, Matteucci G, Magnani F, Nabuurs GJ, Verbeeck H, Sulkava M, van der Werf GR, Janssens IA, Member of the CARBOEUROPE-IP synthesis team (2010) The European carbon balance. part 3: forests. Glob Chang Biol 16:1429-1950

Misir M (2013) Changes in forest biomass carbon stock in northern Turkey between 1973 and 2006. Environ Monit Assess 185:8343-8354

Mohren GMJ, Hasenauer H, Köhl M, Nabuurs G-J (2012) Forest inventories for carbon change assessments. Curr Opin Environ Sustain 4:686-695

Muukkonen P (2005) Needle biomass turnover rates of Scots pine (Pinus sylvestris L.) derived from the needle-shed dynamics. Trees 19:273-279

Muukkonen P (2007) Generalized allometric volume and biomass equations for some tree species in Europe. Eur J For Res 126:157-166

Pan Y, Birdsey RA, Fang J, Houghton R, Kauppi PE, Kurz WA, Phillips OL, Shvidenko A, Lewis SL, Canadell JG, Ciais P, Jackson RB, Pacala SW, McGuire AD, Piao S, Rautiainen A, Sitch S, Hayes D (2011) A large and persistent carbon sink in the world's forests. Science 333:988-993

Park CW, Lee J, Yi M, Kim C, Park GS, Kim RH, Lee KH, Son Y (2013a) Estimation of change in soil carbon stock of Pinus densiflora forests in Korea using KFSC model under RCP 8.5 climate change scenario (in Korean with English summary). Clim Chang Res 4:77-93

Park C-W, Yi K, Lee J, Lee K-H, Yi M-J, Kim C, Park G-S, Kim R, Son Y (2013b) Estimation of long-term effects of harvest interval and intensity, and post-harvest residue management on the soil carbon stock of Pinus densiflora stands using KFSC model (in Korean with English summary). J Korean For Soc 102:82-89

Peltoniemi M, Palosuo T, Monni S, Mäkipää R (2006) Factors affecting the uncertainty of sinks and stocks of carbon in Finnish forests soils and vegetation. For Ecol Manag 232:75-85

Petersson H, Ståhl G (2006) Functions for below-ground biomass of Pinus sylvestris, Piceea abies, Betula pendula and Betula pubescens in Sweden. Scand J For Res 21:84-93 
Pilli R, Grassi G, Kurz WA, Smyth CE, Blujdea V (2013) Application of the CBM-CFS3 model to estimate Italy's forest carbon budget, 1995-2020. Ecol Model 266:144-171

Rantakari M, Lehtonen A, Linkosalo T, Tuomi M, Tamminen P, Heikkinen J, Liski J, Mäkipää R, Ilvesniemi H, Sievänen R (2012) The Yasso07 soil carbon model-testing against repeated soil carbon inventory. For Ecol Manag 286:137-147

Sariyildiz T (2008) Effects of tree canopy on litter decomposition rates of Abies nordmanniana, Picea orientalis and Pinus sylvestris. Scand $\mathrm{J}$ For Res 23:330-338

Sitch S, Huntingford C, Gedney N, Levy PE, Lomas M, Piao SL, Betts R, Ciais P, Cox P, Friedlingstein P, Jones CD, Prentice IC, Woodward FI (2008) Evaluation of the terrestrial carbon cycle, future plant geography and climate-carbon cycle feedbacks using five Dynamic Global Vegetation Models (DGVMs). Glob Chang Biol 14:2015-2039

Sivrikaya F, Baskent EZ, Bozali N (2013) Spatial dynamics of carbon storage: a case study from Turkey. Environ Monit Assess $185: 9403-9412$

Tewari VP (2015) Forest inventory, assessment, and monitoring, and long-term forest observational studies, with special reference to India. For Sci Technol:1-9. doi: 10.1080/21580103.2015.1018962

Tolunay D (2011) Total carbon stocks and carbon accumulation in living tree biomass in forest ecosystems of Turkey. Turk J Agric For 35:265-279

Tolunay D, Çömez A (2008) Türkiye ormanlarında toprak ve ölü örtüde depolanmıs organik karbon miktarları (in Turkish). In: Hava Kirliliği ve Kontrolü Ulusal Sempozyumu Bildiri Kitab1, Hatay, pp 750-765
Vanninen P, Ylitalo H, Sievänen R, Mäkelä A (1996) Effects of age and site quality on the distribution of biomass in Scots pine (Pinus sylvestris L.). Trees 10:231-238

Verkerk PJ, Lindner M, Zanchi G, Zudin S (2011) Assessing impacts of intensified biomass removal on deadwood in European forests. Ecol Indic 11:27-35

Vucetich JA, Reed DD, Breymeyer A, Degórski M, Mroz GD, Solon J, Roo-Zielinska E, Noble R (2000) Carbon pools and ecosystem properties along a latitudinal gradient in northern Scots pine (Pinus sylvestris) forests. For Ecol Manag 136:135-145

Wang W, Wei X, Liao W, Blanco JA, Liu Y, Liu S, Liu G, Zhang L, Guo X, Guo S (2013) Evaluation of the effects of forest management strategies on carbon sequestration in evergreen broad-leaved (Phoebe bournei) plantation forests using FORECAST ecosystem model. For Ecol Manag 300:21-32

Yi K, Park C-W, Ryu S-R, Lee K-H, Yi M-J, Kim C, Park G-S, Kim R, Son Y (2013) Simulating the soil carbon dynamics of Pinus densiflora forests in central Korea. Scand J For Res 28:241-256

Yolasiğmaz HA, Keles S (2009) Changes in carbon storage and oxygen production in forest timber biomass of Balci Forest Management Unit in Turkey between 1984 and 2006. Afr J Biotechnol 8:4872-4883

Yuan Z, Gazol A, Lin F, Ye J, Shi S, Wang X, Wang M, Hao Z (2013) Soil organic carbon in an old-growth temperate forest: spatial pattern, determinants and bias in its quantification. Geoderma 195-196: $48-55$

Zhu B, Wang X, Fang J, Piao S, Shen H, Zhao S, Peng C (2010) Altitudinal changes in carbon storage of temperate forests on $\mathrm{Mt}$ Changbai, Northest China. J Plant Res 123:439-452 